\title{
Treatment of peripheral diabetic neuropathy in Zucker diabetic fatty (ZDF) rats with cariporide
}

\author{
Sergey Lupachyk ${ }^{1,2}$, Hanna Shevalye ${ }^{1,2}$, Pierre Watcho ${ }^{1}$, Alexander Obrosov $^{1,2}$, \\ Irina G. Obrosova ${ }^{1}$, Mark A. Yorek ${ }^{2^{*}}$ \\ ${ }^{1}$ Pennington Biomedical Research Center, Louisiana State University System, Baton Rouge, USA \\ ${ }^{2}$ Department of Veterans Affairs Iowa City Health Care System and Department of Internal Medicine, University of Iowa, Iowa City, \\ USA; *Corresponding Author: mark-yorek@uiowa.edu
}

Received 23 January 2014; revised 15 February 2014; accepted 22 February 2014

Copyright (C) 2014 Sergey Lupachyk et al. This is an open access article distributed under the Creative Commons Attribution License, which permits unrestricted use, distribution, and reproduction in any medium, provided the original work is properly cited. In accordance of the Creative Commons Attribution License all Copyrights (c) 2014 are reserved for SCIRP and the owner of the intellectual property Sergey Lupachyk et al. All Copyright (C) 2014 are guarded by law and by SCIRP as a guardian.

\section{ABSTRACT}

To determine the effect of $\mathrm{Na}+\mathrm{H}+-$ exchanger-1 on diabetic neuropathy in Type 2 diabetes Zucker diabetic fatty (ZDF) rats and lean controls were treated with cariporide ( 10 or $20 \mathrm{mg} / \mathrm{kg} / \mathrm{d}$ ), a $\mathrm{Na}+/ \mathrm{H}+-$ exchanger-1 inhibitor, for 4 weeks at 15 weeks of age. Neuropathy endpoints included motor (MNCV) and sensory (SNCV) nerve conduction velocities, thermal nociception, tactile allodynia and intraepidermal nerve fiber density. Advanced glycation endproduct and markers of oxidative stress including nitrated protein levels in sciatic nerve and dorsal root ganglion were also evaluated. Expression of $\mathrm{Na}+/ \mathrm{H}+-$ exchanger-1 in dorsal root ganglion neurons was increased in ZDF rats. At 15 weeks of age ZDF rats displayed hyperglycemia, MNCV and SNCV deficits, thermal hypoalgesia and tactile allodynia. At 20 but not $10 \mathrm{mg} / \mathrm{kg} / \mathrm{d}$, cariporide significantly improved MNCV and SNCV deficits, thermal hypoalgesia and tactile allodynia. Cariporide treatment was also associated with reduction of diabetes-induced accumulation of advanced glycation end-product (AGE), oxidative stress and nitrated proteins in sciatic nerve and dorsal root ganglion neurons. In conclusion, these findings support an important role for $\mathrm{Na}+\mathrm{H}+-$ exchanger-1 in peripheral diabetic neuropathy, and provide rationale for development of $\mathrm{Na}+\mathrm{I}$ $\mathrm{H}+$-exchanger-1 inhibitors for treatment of diabetic neural complications.

\section{KEYWORDS}

Diabetic Neuropathy; Sodium/Hydrogen

\section{Exchanges; Oxidative Stress}

\section{INTRODUCTION}

After many years of research the only recommended treatment for diabetic peripheral neuropathy is good glycemic control [1]. Hyperglycemia is a major contributing factor to the pathology of diabetic complications but the intracellular metabolic pathways linking excess glucose to peripheral nerve injury are not completely understood making identification of effective treatments based on metabolic dysfunction difficult [2-5]. A consequence of hyperglycemia that has attracted our interest is that inhibition or insufficient activation of the glycolytic enzyme glyceraldehyde 3-phosphate dehydrogenase associated with diabetes underlies diversion of excessive glycolytic flux towards the formation of methylglyoxal and $\alpha$-glycerophosphate [6-10]. This, in turn, has been shown to lead to 1 ) a decrease in free cytosolic $\mathrm{NAD}^{+} / \mathrm{NADH}$ ratio and resulting activation of the superoxide-generating enzyme, NAD(P)H oxidase, and 2) a formation of advanced glycation end-products that generate free radicals during interaction with their receptors [11-13]. The mechanism(s) underlying diabetes-associated activation of the upper part of glycolysis remain unidentified. One mechanism we have been investigating is the activation of $\mathrm{Na}^{+} / \mathrm{H}+$-exchanger- 1 [10]. $\mathrm{Na}+/ \mathrm{H}+$-exchanger- 1 is ubiquitously distributed in mammalian tissues and plays an important role in regulation of intracellular $\mathrm{pH}$ by removing protons that are continuously generated in normal cells [14-20]. Several reports suggest that upregulation of $\mathrm{Na}+/ \mathrm{H}^{+}-$exchanger- 1 activity, recently demonstrated in several tissue-sites for diabetes complications, leads to an increase in cytosolic $\mathrm{pH}$ and consequent activation of glucose transport and all enzymes in 
the upper part of glycolysis, especially, phosphofructokinase [21-23]. We have recently demonstrated in a rat model of Type 1 diabetes that increased expression/activation of $\mathrm{Na}+/ \mathrm{H}^{+}$-exchanger-1 may lead to an increase in the formation of advanced glycation end-products that contributed to an increase in oxidative stress and development of peripheral diabetic neuropathy, which was prevented by inhibition of $\mathrm{Na}+/ \mathrm{H}+$-exchanger- 1 [10]. To test the universality of this finding we have performed a similar set of experiments using Zucker diabetic fatty (ZDF) rats as a model of Type 2 diabetes.

\section{MATERIALS AND METHODS}

Materials: Unless stated otherwise all chemicals used in these studies were obtained from Sigma Chemical Co. (St. Louis, MO).

Animals: The experiments were performed in accordance with regulations by the National Institutes of Health Principles of Laboratory Animal Care, and the Pennington Biomedical Research Center. Male ZDF and lean littermate controls were purchased from Charles River, (Wilmington, MA) at 6 weeks of age. Both ZDF rats and lean littermates were fed a high fat diet (Harland 7013) as described by Charles River and had access to water ad libitum. After 15 weeks rats were divided into six experimental groups; control and diabetic rats were treated with or without cariporide, $\mathrm{Na}+/ \mathrm{H}+$-exchanger- 1 inhibitor, (10 or $20 \mathrm{mg} / \mathrm{kg} /$ day in the drinking water) for 4 weeks [18].

Behavioral tests: The paw withdrawal latency in response to radiant heat was recorded at a $15 \%$ intensity (heating rate of $\sim 1.3{ }^{\circ} \mathrm{C} / \mathrm{sec}$ ) with a cutoff time of $30 \mathrm{sec}$ using the IITC model 336 TG combination tail-flick and paw algesia meter (IITC Life Sciences, Woodland Hills, CA) [24]. Tactile responses were evaluated by quantifying the withdrawal threshold of the hindpaw in response to stimulation with flexible von Frey filaments as previously described [25]. The data were reported in sec and grams, respectively.

Physiological tests: On the day of terminal studies rats were weighed and anesthetized with Nembutal i.p. (50 $\mathrm{mg} / \mathrm{kg}$, i.p., Abbott Laboratories, North Chicago, IL). Non-fasting blood glucose was determined. Sciatic motor nerve conduction velocity and digital sensory nerve conduction velocity were measured as previously described [26]. The motor and sensory nerve conduction velocities were reported in meters per second.

Intraepidermal nerve fiber density: Footpads were fixed in ice-cold Zamboni's fixative for $3 \mathrm{~h}$, washed in $100 \mathrm{mM}$ phosphate-buffered saline (PBS) overnight, and then in PBS containing increasing amounts of sucrose i.e., $10 \%, 15 \%$, and $20 \%, 3 \mathrm{~h}$ in each solution. After washing, the samples were snap frozen in O.C.T. and stored at $-80^{\circ} \mathrm{C}$. Three longitudinal $50 \mu \mathrm{m}$-thick footpad sections were cut using a Leica CM1950 cryostat (Leica Microsystems, Nussloch, Germany). At this point immunohistochemistry analysis of nerve fibers were examined as previously described $[10,26]$.

Western blot analysis of methylglyoxal-derived AGE in rat sciatic nerve: To assess methylglyoxal-derived AGE expression by Western blot analysis, sciatic nerve segments $(\sim 20 \mathrm{mg})$ were placed on ice in $200 \mu \mathrm{l}$ of radioimmunoprecipitation assay buffer (RIPA) containing $50 \mathrm{mmol} / \mathrm{l}$ Tris-HCl, $\mathrm{pH}$ 7.2; $150 \mathrm{mmol} / \mathrm{l} \mathrm{NaCl} ; 0.1 \%$ sodium dodecyl sulfate; $1 \%$ NP-40; 5 mmol/l EDTA; 1 $\mathrm{mmol} / \mathrm{l} \mathrm{EGTA;} \%$ sodium deoxycholate and the protease/ phosphatase inhibitors leupeptin $(10 \mu \mathrm{g} / \mathrm{ml})$, pepstatin $(1 \mu \mathrm{g} / \mathrm{ml})$, aprotinin $(20 \mu \mathrm{g} / \mathrm{ml})$, benzamidine $(10$ $\mathrm{mmol} / \mathrm{l})$, phenylmethylsulfonyl fluoride $(1 \mathrm{mmol} / \mathrm{l})$, sodium orthovanadate $(1 \mathrm{mmol} / \mathrm{l})$, and homogenized on ice [10]. The homogenates were sonicated and centrifuged at $14,000 \mathrm{~g}$ for $20 \mathrm{~min}$. The lysates (40 $\mu \mathrm{g}$ protein) were mixed with equal volumes of $2 x$ sample-loading buffer containing $62.5 \mathrm{mmol} / \mathrm{l}$ Tris-HCl, $\mathrm{pH}$ 6.8; 2\% sodium dodecyl sulfate; $5 \% \quad \beta$-mercaptoethanol; $10 \%$ glycerol and $0.025 \%$ bromophenol blue, and fractionated in $5 \%$ 20\% SDS-PAGE in an electrophoresis cell (Mini-Protean III; Bio-Rad Laboratories, Richmond, CA). Electrophoresis was conducted at $15 \mathrm{~mA}$ constant current for stacking, and at $35 \mathrm{~mA}$ for protein separation. Gel contents were electrotransferred $(80 \mathrm{~V}, 2 \mathrm{~h})$ to nitrocellulose membranes using Mini Trans-Blot cell (Bio-Rad Laboratories, Richmond, CA) and western transfer buffer (25 $\mathrm{mmol} / \mathrm{l} \mathrm{Tris-HCl}, \mathrm{pH}$ 8.3; $192 \mathrm{mmol} / \mathrm{l}$ glycine; and 20\% $(\mathrm{v} / \mathrm{v})$ methanol). Free binding sites were blocked in 5\% $(\mathrm{w} / \mathrm{v})$ BSA (methylglyoxal-derived AGE) diluted in 20 $\mathrm{mmol} / \mathrm{l}$ Tris-HCl buffer, $\mathrm{pH}$ 7.5, containing $150 \mathrm{mmol} / \mathrm{l}$ $\mathrm{NaCl}$ and $0.1 \%$ Tween 20, for $1 \mathrm{~h}$. After blocking free binding sites, primary antibodies to methylglyoxal-derived AGE (Trans Genic Inc., Kumamoto, Japan) were applied overnight, at $4^{\circ} \mathrm{C}$. Then the anti-mouse secondary antibody was applied at room temperature for $1 \mathrm{~h}$. Protein bands detected by the antibodies were visualized with Amersham ECL TM Western Blotting Detection Reagent (Little Chalfont, Buckinghamshire, UK). Afterwards, the membranes were stripped and reprobed with $\beta$-actin antibody to confirm equal protein loading. Stripping was conducted in $25 \mathrm{mmol} / \mathrm{l}$ glycine-HCl, pH 2.5 buffer containing $2 \%$ SDS. The data were quantified by densitometry (Quantity One 4.5.0 software, Bio-Rad Laboratories, Richmond, CA).

ELISA measurements of 4-hydroxynonenal adducts and nitrotyrosine in rat sciatic nerve: For 4-hydroxynonenal adduct measurements, the samples were homogenized in $20 \mathrm{mmol}$ PBS, pH $7.4(1: 10, \mathrm{w} / \mathrm{v})$, on ice [10]. Homogenates were centrifuged at $14,000 \mathrm{~g}\left(4^{\circ} \mathrm{C}, 20 \mathrm{~min}\right)$. Supernatants were used for measurements of 4-hydroxynonenal adducts with the OxiSelect ${ }^{\mathrm{TM}} \mathrm{HNE}$-His Adduct 
ELISA kit (Cell BioLabs, Inc., San Diego, CA). For nitrotyrosine measurements, the samples were homogenized on ice in RIPA buffer $(1: 10 \mathrm{w} / \mathrm{v})$ containing 50 $\mathrm{mmol} / \mathrm{l}$ Tris-HCl, pH 7.2; $150 \mathrm{mmol} / \mathrm{l} \mathrm{NaCl} ; 0.1 \%$ sodium dodecyl sulfate; 1\% NP-40; 5 mmol/l EDTA; 1 mmol/l EGTA; 1\% sodium deoxycholate; and containing the protease/phosphatase inhibitors leupeptin $(10 \mu \mathrm{g} / \mathrm{ml})$; aprotinin $(20 \mu \mathrm{g} / \mathrm{ml})$; benzamidine $(10 \mathrm{mmol} / \mathrm{l})$; phenylmethylsulfonyl fluoride (1 mmol/l); and sodium orthovanadate $(1 \mathrm{mmol} / \mathrm{l})$. Homogenates were sonicated $(3 \times 5$ s) and centrifuged at $14,000 \mathrm{~g}\left(4^{\circ} \mathrm{C}, 20 \mathrm{~min}\right)$. Supernatants were used for measurements of nitrotyrosine concentrations with the OxiSelect Nitrotyrosine ELISA kit (Cell Biolabs, Inc., San Diego, CA). 4-HNE adducts and nitrotyrosine concentrations were normalized per milligram of protein. Protein was measured with the bicinchoninic acid protein assay (Pierce Biotechnology, Rockford, IL).

Fluorescent immunohistochemistry in dorsal root ganglia: Dorsal root ganglia were dissected and fixed in normal buffered $4 \%$ formaldehyde for $24 \mathrm{~h}$ at $4^{\circ} \mathrm{C}$, dehydrated and embedded in paraffin [10]. Analysis of nitrotyrosine and $\mathrm{Na}+\mathrm{H}+$-exchanger-1levels was conducted as previously described [10]. Nitrotyrosine and $\mathrm{Na}+\mathrm{H}+-$ exchanger-1 fluorescence intensity of individual DRG neurons was quantified using the ImageJ software (National Institutes of Health), and normalized per neuronal area. For nitrotyrosine immunofluorescence analysis, nuclei of individual cells were excluded from the regions of interest. Neurons (10 - 28 per rat) were counted, and the average values for each animal were used to calculate group means. Fluorescence intensity was expressed as mean \pm SEM for each experimental group.

Statistical analysis: The results are presented as mean \pm S.E.M. Data were subjected to equality of variance $F$ test and then to log transformation, if necessary before one-way analysis of variance. Where overall significance ( $p<0.05$ ) was attained, individual between-group comparisons for multiple groups were made using the Student-Newman-Keuls multiple-range test. When betweengroup variance differences could not be normalized by log transformation (datasets for body weights and plasma glucose), the data were analyzed by the nonparametric Kruskal-Wallis one-way analysis of variance, followed by the Bonferroni/Dunn test for multiple comparisons. Individual pair-wise comparisons in Table 1 were made using the unpaired two-tailed Student $t$ test. Significance was defined at $\mathrm{p}<0.05$.

\section{RESULTS}

Baseline changes in $\mathrm{ZDF}$ rats prior to treatment. ZDF rats spontaneously become hyperglycemic at about 6 - 8 weeks of age $[27,28]$. For these studies cariporide treat-
Table 1. Effect of diabetes on blood glucose, thermal algesia, tactile response, intraepidermal nerve fiber density and motor and sensory nerve conduction velocity.

\begin{tabular}{ccc}
\hline Determination & $\begin{array}{c}\text { Control } \\
(12)\end{array}$ & $\begin{array}{c}\text { ZDF } \\
(12)\end{array}$ \\
\hline Blood glucose (mM) & $6.2 \pm 0.1$ & $22.7 \pm 0.4^{*}$ \\
Thermal response latency (sec) & $10.9 \pm 0.6$ & $17.0 \pm 0.5^{*}$ \\
Tactile response threshold (g) & $14.4 \pm 1.6$ & $7.2 \pm 2.1^{*}$ \\
Intraepidermal nerve fiber density & $22.5 \pm 1.3$ & $16.7 \pm 0.7^{*}$ \\
(profiles/mm) & $55.9 \pm 1.4$ & $50.0 \pm 1.9^{*}$ \\
MNCV (m/sec) & $36.9 \pm 0.9$ & $33.3 \pm 0.6^{*}$ \\
\hline SNCV (m/sec)
\end{tabular}

Zucker diabetic fatty (ZDF) rats and age matched ZDF lean (control) rats were examined at 15 weeks of age. Data are presented as the mean \pm SEM. ${ }^{*}$ p $<0.05$ compared to control. Number in parentheses indicates the number of experimental animals.

ment of ZDF rats was started at 15 weeks of age. At 15 weeks of age ZDF rats were hyperglycemic and the common diabetic neuropathy endpoints thermal sensitivity, tactile response, motor and sensory nerve conduction velocity and intraepidermal nerve fiber density were all significantly impaired compared to lean rats (controls) (Table 1).

Effect of treatment of $Z D F$ rats with cariporide on body weight and blood glucose. Data in Table 2 demonstrate that treating ZDF or lean rats for 4 weeks with 10 or $20 \mathrm{mg} / \mathrm{kg} /$ day cariporide, an inhibitor of $\mathrm{Na}+\mathrm{H}+-$ exchanger-1, did not significantly affect weight gain or hyperglycemia.

Effect of treatment of ZDF rats with cariporide on neural complications. Data in Table 2 demonstrate that 4 weeks of treatment with $10 \mathrm{mg} / \mathrm{kg} /$ day cariporide significantly improved motor nerve conduction velocity but not sensory nerve conduction velocity, thermal response latency or tactile response threshold compared to untreated ZDF rats. However, when the dose of cariporide was increased to $20 \mathrm{mg} / \mathrm{kg} /$ day motor and sensory nerve conduction velocity, thermal response latency and tactile response threshold were all significantly improved compared to untreated ZDF rats. Data in Figure 1 demonstrate that treating ZDF rats for 4 weeks with 20 $\mathrm{mg} / \mathrm{kg} /$ day cariporide stimulated recovery of intraepidermal nerve fibers in the hindpaw. Treatment of lean rats with 10 or $20 \mathrm{mg} / \mathrm{kg} /$ day cariporide for 4 weeks did not affect neural endpoints.

Effect of treatment of ZDF rats with cariporide on advanced glycation end-products, nitrated proteins and 4-hydroxynonenal in sciatic nerve. Data in Figure 2 demonstrate that methylglyoxal-derived advanced glycation end-products are significantly increased in the sciatic nerve of ZDF rats. Treating ZDF rats for 4 weeks with $20 \mathrm{mg} / \mathrm{kg} /$ day cariporide significantly reduced these protein markers associated with advanced glycation endproduct accumulation. Data in Table 3 demonstrate that 
Table 2. Body weight, blood glucose, motor and sensory nerve conduction velocity, thermal algesia and tactile response in lean and ZDF rats treated with or without cariporide for 4 weeks.

\begin{tabular}{|c|c|c|c|c|c|c|}
\hline Determination & $\begin{array}{c}\text { Control } \\
\text { (12) }\end{array}$ & $\begin{array}{c}\text { Control + } 10 \\
\text { cariporide } \\
(12)\end{array}$ & $\begin{array}{c}\text { Control + } 20 \\
\text { cariporide } \\
(12)\end{array}$ & $\begin{array}{l}\text { ZDF } \\
(12)\end{array}$ & $\begin{array}{c}\mathrm{ZDF}+10 \\
\text { cariporide } \\
(12)\end{array}$ & $\begin{array}{c}\mathrm{ZDF}+20 \\
\text { cariporide } \\
\quad(12)\end{array}$ \\
\hline Final weight (g) & $381 \pm 4$ & $370 \pm 8$ & $374 \pm 5$ & $402 \pm 9$ & $386 \pm 10$ & $372 \pm 11$ \\
\hline Blood glucose (mM) & $6.2 \pm 0.1$ & $6.1 \pm 0.1$ & $6.5 \pm 0.1$ & $23.4 \pm 1.2^{*}$ & $22.8 \pm 0.7^{*}$ & $20.0 \pm 0.1^{*}$ \\
\hline $\operatorname{MNCV}(\mathrm{m} / \mathrm{sec})$ & $56.9 \pm 1.1$ & $55.3 \pm 1.1$ & $57.1 \pm 1.0$ & $45.5 \pm 1.2^{*}$ & $51.4 \pm 0.8^{*, \#}$ & $53.7 \pm 1.3^{*, \#}$ \\
\hline Thermal response latency (sec) & $10.9 \pm 0.4$ & $11.4 \pm 0.6$ & $11.8 \pm 0.7$ & $18.5 \pm 0.6^{*}$ & $16.9 \pm 0.7^{*}$ & $12.9 \pm 0.5^{*, \#}$ \\
\hline Tactile response threshold (g) & $20.8 \pm 1.2$ & $22.0 \pm 1.1$ & $18.7 \pm 1.2$ & $6.5 \pm 0.7^{*}$ & $7.8 \pm 0.3^{*}$ & $13.0 \pm 1.6^{*, \#}$ \\
\hline
\end{tabular}

Zucker diabetic fatty (ZDF) rats and age matched ZDF lean (control) rats at 15 weeks of age were treated for 4 weeks with two doses of cariporide (10 or 20 $\mathrm{mg} / \mathrm{kg} /$ day). The initial weight for lean and ZDF rats at 15 weeks of age was $343 \pm 3$ and $374 \pm 6^{*}$, respectively. Data are presented as the mean \pm SEM. ${ }^{*}<0.05$ compared to control, ${ }^{\sharp} \mathrm{p}<0.05$ compared to untreated diabetic. Number in parentheses indicates the number of experimental animals.

Table 3. 4-hydroxynonenal adduct and nitrotyrosine concentrations in the sciatic nerve in lean and ZDF rats treated with or without cariporide for 4 weeks.

\begin{tabular}{|c|c|c|c|c|}
\hline Determination & $\begin{array}{l}\text { Control } \\
(10)\end{array}$ & $\begin{array}{c}\text { Control + cariporide } \\
\text { (10) }\end{array}$ & $\begin{array}{l}\text { ZDF } \\
(10)\end{array}$ & $\begin{array}{c}\text { ZDF + cariporide } \\
\text { (10) }\end{array}$ \\
\hline 4-Hydroxynonenal adducts (pmol/mg protein) & $26.8 \pm 2.0$ & $26.5 \pm 2.3$ & $32.4 \pm 1.9^{*}$ & $26.2 \pm 1.1^{\#}$ \\
\hline Nitrotyrosine (pmol/mg protein) & $39.2 \pm 6.2$ & $31.3 \pm 4.3$ & $167.9 \pm 25.3^{*}$ & $105.3 \pm 12.4^{*, \#}$ \\
\hline
\end{tabular}

Zucker diabetic fatty (ZDF) rats and age matched ZDF lean (control) rats at 15 weeks of age were treated for 4 weeks with cariporide (20 mg/kg/day). Data are presented as the mean \pm SEM. ${ }^{*} \mathrm{p}<0.05$ compared to control, ${ }^{\#} \mathrm{p}<0.05$ compared to untreated diabetic. Number in parentheses indicates the number of experimental animals.
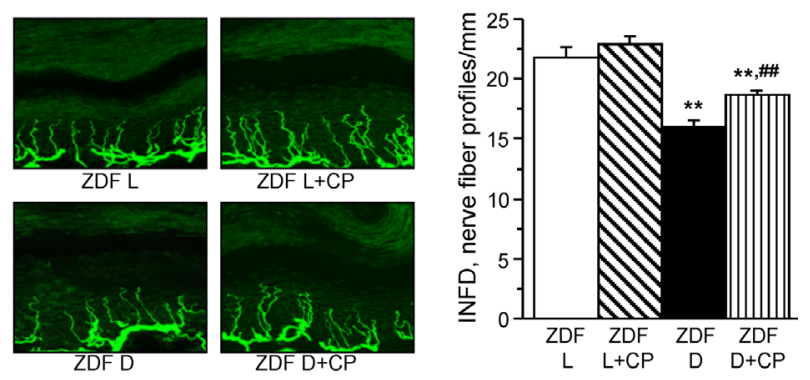

Figure 1. (left) Representative images of intraepidermal nerve fiber profiles, magnification $x$ 400. (right) Intraepidermal nerve fiber densities inlean ZDF rats (ZDF L) and ZDF diabetic (ZDF D) rats at 19 weeksof age maintained with or without 20 $\mathrm{mg} / \mathrm{kg} /$ day cariporide (CP) treatment for 4 weeks at 15 weeks of age. Mean \pm SEM, $n=10$ per group. ${ }^{* *} \mathrm{p}<0.01$ vs. ZDF lean rats, ${ }^{\#} \mathrm{p}<0.01$ vs. untreated ZDF diabetic rats.

4-hydroxynonenal adducts and nitrotyrosine levels are significantly increased in the sciatic nerve of ZDF rats and that these markers of oxidative and nitrosative stress are improved with cariporide treatment (20 mg/kg/day) for 4 weeks. Treatment of lean rats with cariporide for 4 weeks did not affect the presence of these pathological markers in the sciatic nerve.

Effect of treatment of ZDF rats with cariporide on expression of $\mathrm{Na}+/ \mathrm{H}+-$ exchanger-1 and nitrated proteins in dorsal root ganglion neurons. In this study, we determined if $\mathrm{Na}+/ \mathrm{H}+$-exchanger- 1 overexpression occurs in dorsal root ganglion neurons and whether it is related to oxidative-nitrosative stress. ZDF rats were treated with
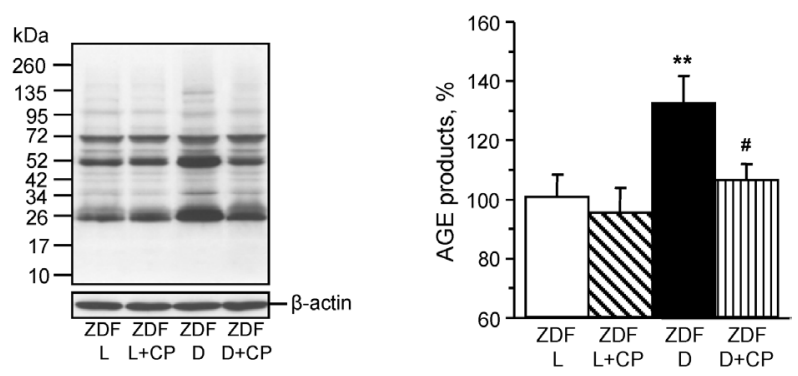

Figure 2. (left) Representative Western blot and (right) analysis bydensitometry of rat sciatic nerve of expression of methylglyoxal-derived AGE. Lean ZDF rats (ZDF L) and ZDF diabetic (ZDF D) rats at 19 weeksof age maintained with or without 20 $\mathrm{mg} / \mathrm{kg} /$ day cariporide (CP) treatment for 4 weeks at 15 weeks of age. Control was arbitrarily assigned a value of $100 \%$. Mean \pm SEM, $\mathrm{n}=10$ per group. ${ }^{* *} \mathrm{p}<0.01$ vs. ZDF lean rats, ${ }^{*} \mathrm{p}<0.05$ vs. untreated ZDF diabetic rats.

the $\mathrm{Na}+\mathrm{H}+$-exchanger- 1 inhibitor cariporide at the dose of $20 \mathrm{mg} / \mathrm{kg} / \mathrm{d}$ for 4 weeks after 15 weeks of age. Expression of $\mathrm{Na}+\mathrm{H}+$-exchanger- 1 is increased in dorsal root ganglion neurons from untreated diabetic rats compared to neurons from lean ratsand after 4 weeks of treatment with cariporide the expression of $\mathrm{Na}+/ \mathrm{H}+-$ exchanger-1 remained significantly higher and was not significantly different compared to untreated ZDF rats (Figure 3). Nitrotyrosine fluorescence was increased in dorsal root ganglion neurons of untreated ZDF rats, indicative of neuronal oxidative-nitrosative stress (Figure 4). Treating ZDF rats with cariporide significantly decreased 


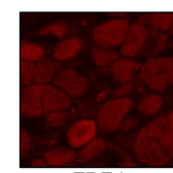

ZDF L

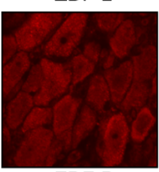

ZDF D

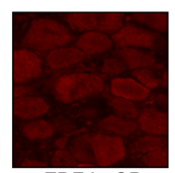

ZDF L+CP

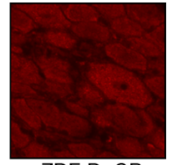

ZDF D+CP

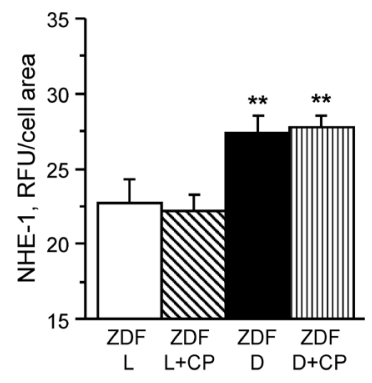

Figure 3. (left) Representative images of dorsal root ganglion neurons stained for $\mathrm{Na}+\mathrm{H}+$-exchanger- 1 ; and (right) analysis of fluorescence as relative light units (RLU) for $\mathrm{Na}+\mathrm{H}+-\mathrm{ex}-$ changer-1 staining. Lean ZDF rats (ZDF L) and ZDF diabetic (ZDF D) rats at 19 weeks of age maintained with or without 20 $\mathrm{mg} / \mathrm{kg} /$ day cariporide (CP) treatment for 4 weeks at 15 weeks of age. Mean \pm SEM, $n=7$ - 9 (11 - 21 neurons were counted per rat). ${ }^{* *} \mathrm{p}<0.01$ vs. ZDF lean rats, ${ }^{\# \#} \mathrm{p}<0.01$ vs. untreated ZDF diabetic rats.
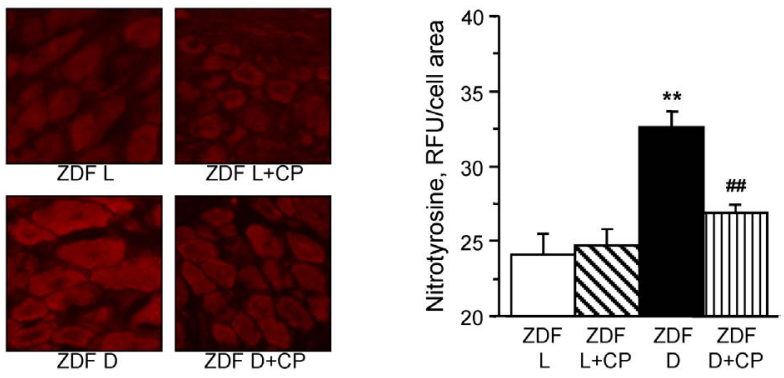

Figure 4. (left) Representative images of dorsal root ganglion neurons stained for nitrotyrosine; and (right) analysis of fluorescence as RLU for nitrotyrosine staining. Lean ZDF rats (ZDF L) and ZDF diabetic (ZDF D) rats at 19 weeks of age maintained with or without $20 \mathrm{mg} / \mathrm{kg} /$ day cariporide (CP) treatment for 4 weeks at 15 weeks of age. Mean \pm SEM, $n=7-$ 9 (10 - 28 neurons were counted per rat. ${ }^{* *}$ p $<0.01$ vs. ZDF lean rats, ${ }^{\#} \mathrm{p}<0.01$ vs. untreated ZDF diabetic rats.

nitrotyrosine staining in dorsal root ganglion neurons (Figure 4).

\section{DISCUSSION}

We previously demonstrated that treating a Type 1 diabetic rat model with cariporide, a $\mathrm{Na}+/ \mathrm{H}+$-exchanger-1 inhibitor, for four weeks after 12 weeks of untreated hyperglycemia improved multiple diabetic neuropathy endpoints [10]. In this study we investigated whether inhibition of $\mathrm{Na}+\mathrm{H}+$-exchanger- 1 was an effective treatment for diabetic neuropathy in ZDF rats, a model for Type 2 diabetes. In this model, all fatty males become hyperglycemic by 8 weeks of age and glucose remains elevated throughout their lifespan [28]. Initially, ZDF rats are hyperinsulinemic. However, with age serum insulin levels decline to below the levels of insulin in age-matched lean control rats [28-30]. A similar characteristic is seen in human Type 2 diabetes, which is thought to be caused by pancreas/ $\beta$-cell exhaustion [10].
One limitation using the ZDF Type 2 diabetic model is the restriction of the studies to male rats. This can raise the issue of translational significance when limiting studies to only one gender. Previously we demonstrated that the development of diabetic neuropathy in ZDF rats was progressive and a difficult condition to reverse [29,30]. We found that treating ZDF rats with different classes of drugs including enalapril, an angiotensin converting enzyme inhibitor, $\alpha$-lipoic acid, an antioxidant, rosuvastatin, an HMG-CoA reductase inhibitor, or rosiglitazone, a thiazolidinedione which binds to and activates the peroxisome proliferator-activated receptors- $\gamma$ only partially improved diabetic neuropathy [30]. A common mechanism of interaction for these drugs was to reduce oxidative and inflammatory stress [30]. With cariporide we found that it also reduced oxidative and nitrosative stress in Type 1 diabetic rats but it was unknown what efficacy it may have in a Type 2 diabetic rat model [10].

The $\mathrm{Na}+\mathrm{H}+$-exchanger- 1 isoform is found in the plasma membrane of most mammalian cells and is normally described as the housekeeping isoform [22]. $\mathrm{Na}+/$ $\mathrm{H}+$-exchanger-1 plays a critical role in intracellular $\mathrm{pH}$ and cell volume homeostasis and regulates a number of cell behaviors, including adhesion, shape determination, migration, and proliferation [14,31]. Another important function of $\mathrm{Na}+/ \mathrm{H}+-$ exchanger- 1 is regulation of glycolysis. Activation of $\mathrm{Na}+\mathrm{H}+-$ exchanger- 1 causes cytosol alkalinization and activation of glycolysis. Recently, a $\mathrm{Na}+-\mathrm{H}+$-exchange dependent increase of intracellular $\mathrm{pH}$ by $\sim 0.3$ units was found to cause a one order magnitude increase in the rate of glycolysis [32-35]. It is well known that upregulation of glycolysis contributes to the formation of by-products of glycolysis i.e., methylglyoxal, $\alpha$-glycerophosphate, and diacylglycerol, with concomitant activation of advanced glycation end-product formation, which has been associated with the development of diabetes complications including diabetic neuropathy [36,37].

Hyperglycemia is associated with stimulation of $\mathrm{Na}+$ / $\mathrm{H}+$-exchanger-1 [22,38]. In the diabetic kidney it has been demonstrated that $\mathrm{Na}+\mathrm{H}+$-exchanger-3 activity is increased [22]. We have shown that in the sciatic nerve and dorsal root ganglion Type 1 diabetes increases the expression of $\mathrm{Na}+/ \mathrm{H}+$-exchanger- 1 and in this study we demonstrated that $\mathrm{Na}+/ \mathrm{H}+$-exchanger- 1 expression is increased in the dorsal root ganglion neurons from a Type 2 diabetic rat model [10]. Hyperglycemia and oxidative stress both stimulate $\mathrm{Na}+\mathrm{H}+$-exchanger-3 activity via angiotensin II receptor activation [22]. Angiotensin converting enzyme inhibitors and angiotensin receptor blockers reduce progression of diabetic nephropathy and we have shown that these drugs also improve diabetic neuropathy [27,39-42]. It is unknown if angiotensin converting enzyme inhibitors or angiotensin re- 
ceptor blockers decrease $\mathrm{Na}+/ \mathrm{H}+$-exchanger- 1 activity in diabetes. However, these data imply that one possible mechanism for the beneficial effects of angiotensin converting enzyme inhibitors or angiotensin receptor blockers on diabetic complications including neuropathy may be through inhibiting the activation of $\mathrm{Na}+/ \mathrm{H}^{+}-$exchangers.

Hyperglycemia and increased metabolic rate could accentuate proton production and lead to increased proton efflux through $\mathrm{Na}+/ \mathrm{H}+$ exchange, which would stimulate $\mathrm{Na}^{+} / \mathrm{Ca}^{2+}$ exchange and calcium overload [38]. Imbalance of sodium and calcium with hyperglycemia is associated with endothelial dysfunction and apoptosis [38], proliferation of vascular smooth muscle cells [43], retinal microangiopathy and ischemic damage $[18,44]$, and myocardial damage [45-47]. It has been shown that inhibition of $\mathrm{Na}+/ \mathrm{H}^{+}$-exchanger-1 yields beneficial effects on diabetes vascular, retinal and renal complications but until our studies no information was available whether inhibiting $\mathrm{Na}+/ \mathrm{H}+$-exchanger- 1 improves diabetic peripheral neuropathy $[10,18,22]$.

In this study we demonstrated that after about 7 - 8 weeks of hyperglycemia expression of $\mathrm{Na}+/ \mathrm{H}+-e x-$ changer- 1 was increased in dorsal root ganglion neurons from ZDF rats and that subsequent cariporide treatment for 4 weeks improved neural defects of diabetic neuropathy including nerve conduction velocity, thermal and tactile sensitivity and regeneration of intraepidermal nerve fibers without reducing the expression of $\mathrm{Na}+/ \mathrm{H}+-$ exchanger-1 in dorsal root ganglion neurons. Improvement in diabetic neuropathy endpoints with cariporide treatment was associated with reduction of oxidative stress in sciatic nerve and dorsal root ganglion neurons and reduction of a marker of advanced glycation endproduct in sciatic nerve. Overall, the results from this study were similar to the results we obtained treating Type 1 diabetic rats with cariporide except for the concentration required to achieve a significant improvement in diabetic neuropathy endpoints [10]. In our studies with Type 1 diabetic rats of a longer duration of hyperglycemia than in these studies treating diabetic rats for four weeks with $10 \mathrm{mg} / \mathrm{kg} / \mathrm{rat}$ cariporide was sufficient to achieve a significant improvement in diabetic neuropathy [10]. However, in these studies treating ZDF rats with 10 $\mathrm{mg} / \mathrm{kg} / \mathrm{rat}$ cariporide for four weeks after 7 - 8 weeks of untreated diabetes had little to no effect on improving diabetic neuropathy. A higher dose of cariporide, 20 $\mathrm{mg} / \mathrm{kg} /$ day, was required to achieve a similar improvement in diabetic neuropathy in Type 2 diabetic rats compared to a Type 1 diabetic rat model. This supports our previous findings that reversal of diabetic neuropathy is more difficult in Type 2 diabetes. This would suggest that early intervention and more aggressive therapy may be needed for treatment of diabetic neuropathy in Type 2 diabetic patients.

In summary, it is widely believed that oxidative stress plays an important role in the pathogenesis of peripheral diabetic neuropathy and that several pathways activated by hyperglycemia contribute to the generation of reactive oxygen/nitrogen species. We have shown that $\mathrm{Na}+/ \mathrm{H}^{+}-$ exchanger-1 is overexpressed in peripheral nerve and contributes to the accumulation of markers for oxidative/ nitrosative stress and advanced glycation end-products [10]. Inhibiting $\mathrm{Na}+-\mathrm{H}+-$ exchanger- 1 in Type 1 and Type 2 diabetic rats reduced the levels of these markers in nerve and improved diabetic neuropathy [10]. These studies provide rationale for further development of $\mathrm{Na}^{+}$/ $\mathrm{H}+$-exchanger-1 inhibitors for treatment of diabetic neural complications.

\section{ACKNOWLEDGEMENTS}

This material is based upon work supported in part by the Department of Veterans Affairs, Veterans Health Administration, Office of Research and Development, Biomedical Laboratory Research and Development (BX001680-01, MAY), by National Institute of Diabetes and Digestive and Kidney Diseases Grant DK073990 (MAY) and DK077141 (IGO and MAY) from NIH. The content of this manuscript are new and solely the responsibility of the authors and do not necessarily represent the official views of the granting agencies.

\section{REFERENCES}

[1] Callaghan, B.C., Little, A.A. and Feldman, E.L. and Hughes, R.A. (2012) Enhanced glucose control for preventing and treating diabetic neuropathy. Cochrane database of systematic reviews, 6, Article ID: CD007543.

[2] Vincent, A.M., Callaghan, B.C., Smith, A.L. and Feldman, E.L. (2011) Diabetic neuropathy: Cellular mechanisms as therapeutic targets. Nature Reviews Neurology, 7, 573583. http://dx.doi.org/10.1038/nrneurol.2011.137

[3] Vincent, A.M., Hinder, L.M., Pop-Busui, R. and Feldman, E.L. (2009) Hyperlipidemia: A new therapeutic target for diabetic neuropathy. Journal of the Peripheral Nervous System, 14, 257-267. http://dx.doi.org/10.1111/j.1529-8027.2009.00237.x

[4] Obrosova, I.G. (2009) Diabetes and the peripheral nerve. Biochimica et Biophysica Acta, 1792, 931-940. http://dx.doi.org/10.1016/j.bbadis.2008.11.005

[5] Veves, A., Backonja, M. and Malik, R.A. (2008) Painful diabetic neuropathy: Epidemiology, natural history, early diagnosis, and treatment options. Pain Medication, 9, 660-674. http://dx.doi.org/10.1016/j.bbadis.2008.11.005

[6] Beisswenger, P.J., Drummond, K.S., Nelson, R.G., Howell, S.K., Szwergold, B.S. and Mauer, M. (2005) Susceptibility to diabetic nephropathy is related to dicarbonyl and oxidative stress. Diabetes, 54, 3274-3281. http://dx.doi.org/10.2337/diabetes.54.11.3274

[7] Beisswenger, P.J., Howell, S.K., Nelson, R.G., Mauer, M. and Szwergold, B.S. (2003) Alpha-oxoaldehyde metabol- 
ism and diabetic complications. Biochemical Society Transactions, 31, 1358-1363.

http://dx.doi.org/10.1042/BST0311358

[8] Beisswenger, P.J., Howell, S.K., Smith, K. and Szwergold, B.S. (2003) Glyceraldehyde-3-phosphate dehydrogenase activity as an independent modifier of methylglyoxal levels in diabetes. Biochimica et Biophysica Acta, 1637, 98-106. http://dx.doi.org/10.1007/s00125-012-2452-1

[9] Fleming, T., Cuny, J., Nawroth, G., Djuric, Z., Humpert, P.M., Zeier, M., Bierhaus, A. and Nawroth, P.P. (2012) Is diabetes an acquired disorder of reactive glucose metabolites and their intermediates? Diabetologia, 55, 11511155.

[10] Lupachyk, S., Watcho, P., Shevalye, H., Vareniuk, I., Obrosov, A., Obrosova, I.G. and Yorek, M.A. (2013) Na+/ $\mathrm{H}+$ exchanger 1 inhibition reverses manifestation of peripheral diabetic neuropathy in Type 1 diabetic rats. American Journal of Physiology: Journal of Membrane Biology, 305, E396-E404. http://dx.doi.org/10.1152/ajpendo.00186.2013

[11] Askarova, S., Yang, X., Sheng, W., Sun, G.Y. and Lee, J.C. (2011) Role of a $\beta$-receptor for advanced glycation endproducts interaction in oxidative stress and cytosolic phospholipase $\mathrm{A}_{2}$ activation in astrocytes and cerebral endothelial cells. Neuroscience, 199, 375-385. http://dx.doi.org/10.1016/j.neuroscience.2011.09.038

[12] Ding, Y., Kantarci, A., Hasturk, H., Trackman, P.C., Malabanan, A. and Van Dyke, T.F. (2007) Activation of RAGE induces elevated $\mathrm{O}_{2}$-generation by mononuclear phagocytes in diabetes. Journal of Leukocyte Biology, 81, 520-527. http://dx.doi.org/10.1189/jlb.0406262

[13] Yin, Q.Q., Dong, C.F., Dong, S.Q., Dong, X.L., Hong, Y., Hou, X.Y., Luo, D.Z., Pei, J.J. and Liu, X.P. (2012) AGEs induce cell death via oxidative and endoplasmic reticulum stresses in both human SH-SY5Y neuroblastoma cells and rat cortical neurons. Cellular and Molecular Neurobiology, 32, 1299-1309. http://dx.doi.org/10.1007/s10571-012-9856-9

[14] Bkaily, G., Nader, M., Avedanian, L., Jacques, D., Perrault, C., Abdel-Samad, D., D’Orleans-Juste, P., Gobeil, F. and Hazzouri, K.M. (2004) Immunofluorescence revealed the presence of NHE-1 in the nuclear membranes of rat cardiomyocytes and isolated nuclei of human, rabbit, and rat aortic and liver tissues. Canadian Journal of Physiology and Pharmacology, 82, 805-811. http://dx.doi.org/10.1139/y04-119

[15] Ford, P., Rivarola, V., Kierbel, A., Chara, O., Blot-Chabaud, M., Farman, N., Parisi, M. and Capurro, C. (2002) Differential role of $\mathrm{Na}+\mathrm{H}+$ exchange isoforms NHE-1 and NHE-2 in a rat cortical collecting duct cell line. Journal of Membrane Biology, 190, 117-125.

http://dx.doi.org/10.1007/s00232-002-1030-8

[16] Karmazyn, M., Sawyer, M. and Fliegel, L. (2005) The $\mathrm{Na}(+) / \mathrm{H}(+)$ exchanger: A target for cardiac therapeutic intervention. Current Drug Target-Cardiovascular \& Hematological Disorders, 5, 323-335. http://dx.doi.org/10.2174/1568006054553417

[17] Khan, I., Thomas, N. and Haridas, S. (2001) Expression and sub cellular localization of the sodium hydrogen ex- changer isoform-1 in rat tissues: A possible functional relevance. Molecular and Cellular Biochemistry, 219, 153161. http://dx.doi.org/10.1023/A:1010867631953

[18] Lupachyk, S., Stavniichuk, R., Komissarenko, J.I., Drel, V.R., Obrosov, A.A., El-Remessy, A.B., Pacher, P. and Obrosova, I.G. (2012) Na+/H+-exchanger-1 inhibition counteracts diabetic cataract formation and retinal oxidative-nitrative stress and apoptosis. International Journal of Molecular Medicine, 29, 989-998.

[19] Rieder, C.V. and Fliegel, L. (2003) Transcriptional regulation of $\mathrm{Na}+\mathrm{H}+$ exchanger expression in the intact mouse. Molecular and Cellular Biochemistry, 243, 87-95. http://dx.doi.org/10.1023/A:1021643608619

[20] Zhao, P., Ma, M.C., Qian, H. and Xia, Y. (2005) Downregulation of delta-opioid receptors in $\mathrm{Na}+\mathrm{H}+$ exchanger 1 null mutant mouse brain with epilepsy. Neuroscience Research, 53, 442-446. http://dx.doi.org/10.1016/j.neures.2005.09.003

[21] Dyck, J.R. and Lopaschuk, G.D. (1998) Glucose metabolism, $\mathrm{H}+$ production and $\mathrm{Na}+\mathrm{H}+$-exchanger mRNA levels in ischemic hearts from diabetic rats. Molecular and Cellular Biochemistry, 180, 85-93. http://dx.doi.org/10.1023/A:1006891007014

[22] Sun, Y.M., Su, Y., Li, J., Tian, Y. and Wang, L.F. (2012) Role of the $\mathrm{Na}(+) / \mathrm{H}(+)$ exchanger on the development of diabetes mellitus and its chronic complications. Biochemical and Biophysical Research Communications, 427, 229231. http://dx.doi.org/10.1016/j.bbrc.2012.09.050

[23] Wang, S., Peng, Q., Zhang, J. and Liu, L. (2008) Na+/H+ exchanger is required for hyperglycaemia-induced endothelial dysfunction via calcium-dependent calpain. Cardiovascular Research, 80, 255-262. http://dx.doi.org/10.1093/cvr/cvn179

[24] Obrosova, I.G., Pacher, P., Szabo, C., Zsengeller, Z., Hirooka, H., Stevens, M.J. and Yorek, M.A. (2005) Aldose reductase inhibition counteracts oxidative-nitrosative stress and poly(ADP-Ribose) polymerase activation in tissue sites for diabetes complications. Diabetes, 54, 234 242. http://dx.doi.org/10.2337/diabetes.54.1.234

[25] Drel, V.R., Pacher, P., Vareniuk, I., Pavlov, I., Ilnytska, O., Lyzogubov, V.V., Tibrewala, J., Groves, J.T. and Obrosova, I.G.(2007) A peroxynitrite decomposition catalyst counteracts sensory neuropathy in streptozotocin-diabetic mice. European Journal of Pharmacology, 569, 48-58. http://dx.doi.org/10.1016/j.ejphar.2007.05.055

[26] Stavniichuk, R., Drel, V.R., Shevalye, H., Maksimchyk, Y., Kuchmerovska, T.M., Nadler, J.L. and Obrosova, I.G. (2011) Baicalein alleviates diabetic peripheral neuropathy through inhibition of oxidative-nitrosative stress and p38 MAPK activation. Experimental Neurology, 230, 106-113. http://dx.doi.org/10.1016/j.expneurol.2011.04.002

[27] Oltman, C.L., Davidson, E.P., Coppey, L.J., Kleinschmidt, T.L., Lund, D.D. and Yorek, M.A. (2008) Attenuation of vascular/neural dysfunction in Zucker rats treated with enalapril or rosuvastatin. Obesity, 16, 82-89. http://dx.doi.org/10.1038/oby.2007.19

[28] Peterson, R.G., Shaw, W.N. Neel, M.A, Little, L.A. and Eichberg, J. (1990) Zucker diabetic fatty rat as a model for non-insulin-dependent diabetes mellitus. The ILAR 
Journal, 32, 16-19. http://dx.doi.org/10.1093/ilar.32.3.16

[29] Oltman, C.L., Coppey, L.J., Gellett, J.S., Davidson, E.P., Lund, D.D. and Yorek M.A. (2005) Progression of vascular and neural dysfunction in sciatic nerves of Zucker diabetic fatty (ZDF) and Zucker rats. American Journal of Physiology, 289, E113-E122.

[30] Oltman, C.L., Davidson, E.P., Coppey, L.J., Kleinschmidt, T.L., Lund, D.D., Adebara, E.T. and Yorek, M.A. (2008) Vascular and neural dysfunction in Zucker diabetic fatty rats: A difficult condition to reverse. Diabetes, Obesity and Metabolism, 10, 64-74.

[31] Putney, L.K., Denker, S.P. and Barber, D.L. (2002) The changing face of the $\mathrm{Na}+\mathrm{H}+$ exchager, NHE1: Structure, regulation, and cellular actions. Annual Review of Pharmacology and Toxicology, 42, 527-552.

http://dx.doi.org/10.1146/annurev.pharmtox.42.092001.14 $\underline{3801}$

[32] Erecinska, M., Thoresen, M. and Silver, I.A. (2003) Effects of hypothermia on energy metabolism in Mammalian central nervous system. Journal of Cerebral Blood Flow \& Metabolism, 23, 513-530. http://dx.doi.org/10.1097/01.WCB.0000066287.21705.21

[33] Lang, K.S., Mueller, M.M., Tanneur, V., Wallisch, S., Fedorenko, O., Palmada, M., Lang, F., Broer, S., Heilig, C.W., Schleicher, E. and Weigert, C. (2003) Regulation of cytosolic $\mathrm{pH}$ and lactic acid release in mesangial cells overexpressing GLUT1. Kidney International, 64, 13381347. http://dx.doi.org/10.1046/j.1523-1755.2003.00213.x

[34] Peak, M., al-Habori, M. and Agius, L. (1992) Regulation of glycogen synthesis and glycolysis by insulin, $\mathrm{pH}$ and cell volume. Interactions between swelling and alkalinization in mediating the effects of insulin. Biochemical Journal, 28, 797-805.

[35] Reshkin, S.J., Bellizzi, A., Caldeira, S., Albarani, V., Malanchi, I., Poignee, M., Alunni-Fabbroni, M., Casavola, V. andTommasino, M. (2000) $\mathrm{Na}+/ \mathrm{H}+$ exchanger-dependent intracellular alkalinization is an early event in malignant transformation and plays an essential role in the development of subsequent transformation-associated phenotypes. The FASEB Journal, 14, 2185-2197. http://dx.doi.org/10.1096/fj.00-0029com

[36] Jack, M. and Wright, D. (2012) Role of advanced glycation endproducts and glyoxalase I in diabetic peripheral sensory neuropathy. Translational Research, 159, 355365. http://dx.doi.org/10.1016/j.trsl.2011.12.004

[37] Sugimoto, K., Yasujima, M. and Yagihashi, S. (2008) Role of advanced glycation end products in diabetic neuropathy. Current Pharmaceutical Design, 14, 953-961. http://dx.doi.org/10.2174/138161208784139774

[38] Vial, G., Dubouchaud, H., Couturier, K., Lanson, M., Leverve, $\mathrm{X}$. and Demaison, L. (2008) $\mathrm{Na}^{+} / \mathrm{H}^{+}$exchange inhibition with cariporide prevents alterations of coronary endothelial function in streptozotocin-induced diabetes.
Molecular and Cellular Biochemistry, 310, 93-102. http://dx.doi.org/10.1007/s11010-007-9669-1

[39] Coppey, L.J., Davidson, E.P., Rinehart, T.W., Gellett, J.S., Oltman, C.L., Lund, D.D. and Yorek, M.A. (2006) ACE inhibitor or angiotensin II receptor antagonist attenuates diabetic neuropathy in streptozotocin-induced diabetic rats. Diabetes, 55, 341-348. http://dx.doi.org/10.2337/diabetes.55.02.06.db05-0885

[40] Lewis, E.J., Hunsicker, L.G., Bain, R.P. and Rohde, R.D. (1993) The effect of angiotensin-converting-enzyme inhibition on diabetic nephropathy. The Collaborative Study Group. New England Journal of Medicine, 329, 14561462. http://dx.doi.org/10.1056/NEJM199311113292004

[41] Lewis, E.J., Hunsicker, L.G., Clarke, W.R., Berl, T., Pohl, M.A., Lewis, J.B., Ritz, E., Atkins, R.C., Rohde, R. and Raz, I. (2001) Renoprotective effect of the angiotensinreceptor antagonist irbesartan in patients with nephropathy due to Type 2 diabetes. New England Journal of Medicine, 345, 851-860. http://dx.doi.org/10.1056/NEJMoa011303

[42] Yorek, M.A. (2008) The potential role of angiotensin converting enzyme and vasopeptidase inhibitors in the treatment of diabetic neuropathy. Current Drug Targets, 9, 7784. http://dx.doi.org/10.2174/138945008783431736

[43] Hannan, K.M. and Little, P.J. (1998) Mechanisms regulating the vascular smooth muscle $\mathrm{Na} / \mathrm{H}$ exchanger (NHE-1) in diabetes. Biochemistry and Cell Biology, 76, 751-759. http://dx.doi.org/10.1139/o98-093

[44] Cukiernik, M., Hileeto, D., Downey, D., Evans, T., Khan, Z.A., Karmazyn, M. and Chakrabarti, S. (2004) The role of the sodium hydrogen exchanger-1 in mediating diabetesinduced changes in the retina. Diabetes/Metabolism Research and Reviews, 20, 61-71.

http://dx.doi.org/10.1002/dmrr.421

[45] Anzawa, R., Seki, S., Nagoshi, T., Taniguchi, I., Feuvray, D. and Yoshimura, M. (2012) The role of $\mathrm{Na}+\mathrm{H}+$ exchanger in $\mathrm{Ca} 2+$ overload and ischemic myocardial damage in hearts from Type 2 diabetic db/db mice. Cardiovascular Diabetology, 11, 33. http://dx.doi.org/10.1186/1475-2840-11-33

[46] Chen, S., Khan, Z.A., Karmazyn, M. and Chakrabarti, S. (2007) Role of endothelin-1, sodium hydrogen exchanger-1 and mitogen activated protein kinase (MAPK) activation in glucose-induced cardiomyocte hypertrophy. Diabetes/ Metabolism Research and Reviews, 23, 356-367. http://dx.doi.org/10.1002/dmrr.689

[47] Darmellah, A., Baetz, D., Prunier, F., Tamareille, S., RuckerMartin, C. and Feuvray, D. (2007) Enhanced activity of the myocardial $\mathrm{Na}+\mathrm{H}+$ exchanger contributes to left ventricular hypertrophy in the Goto-Kakizaki rat model of Type 2 diabetes: Critical role of Akt. Diabetologia, 50, 1335-13344. http://dx.doi.org/10.1007/s00125-007-0628-x 